\title{
The Effect of Feeding Stimulants in Diet on Digestive Enzyme Activities of Eel
}

\author{
Kenji Takii,* Sadao Shimeno,* Masahiko Takeda,* and Shuji Kamekawa* \\ (Accepted January 20, 1986)
}

\begin{abstract}
Pepsin-like, trypsin-like and amylase activities in the gastrointestinal tissue and their digesta were assayed at 3 and $6 \mathrm{~h}$ interval after feeding a diet flavoured with alanine, glycine, proline, histidine and uridine-5'-monophosphate on the initial day, day 13 and final feeding day of the experiment.

Eel reared on the flavoured diet for 25 days showed remarkably high growth, feed efficiency and energy retention compared with the control group. Although a similar change was recognized in gastric digesta weight of both groups, the flavoured group had significantly higher pepsin-like activities in gastric digesta than the control group. A significant positive correlation between the intestinal digesta weight and trypsin-like activities and high digestibility of dietary protein and carbohydrate were observed in the flavoured dietary group. Whereas higher trypsin-like and amylase activities and digesta weight in intestinal tract were determined in the control group, no relationship between intestinal digesta weight and their trypsin-like activity was recognized. These findings suggest that the feeding stimulants in the diet, stimulates the feeding activity of the fish and promotes the digestion and absorption of the diet.
\end{abstract}

In human beings and other mammals, stimuli of taste, smell and sight are associated with anticipation of eating causing the glandular secretion of digestive fluid, salivary and gastric juice, thus making easy the digestion and absorption in ingested food. ${ }^{1)}$ However in fishes, little is known concerning the effects of feeding stimulants on digestion but growth effects have been examined. ${ }^{2-4}$ )

In a previous paper, ${ }^{2)}$ we reported that eel fed a diet flavoured with the feeding stimulants grew faster than the control. Therefore, we investigated the effects of feeding stimulants on digestive enzyme activity in gastrointestinal tract and its digesta in order to infer the reasons for its good performance.

\section{Materials and Methods}

\section{Fish and Experimental Aquarium}

Eel Anguilla japonica were obtained from an aquacultural farm in Kochi city and transported to the laboratory. Prior to the feeding trials, commercial diet (Nihon Nosan Kogyo Co., Ltd) was fed for 20 days at $27^{\circ} \mathrm{C}$. Groups of $30 \mathrm{fish}$ with mean body weight of $78 \mathrm{~g}$ were separated in two aquariums $(80 \times 60 \times 50 \mathrm{~cm})$ with aerated recirculating well water at $24^{\circ} \mathrm{C}$. Details of experimental conditions were described in the pre- vious paper. ${ }^{2}$

\section{Preparation of Diet}

A paste type flavoured diet was prepared by blending $100 \mathrm{~g}$ of the basal diet with $160 \mathrm{ml}$ water containing the feeding stimulants (Table 1). The $\mathrm{pH}$ of feeding stimulants was adjusted to 6.8 prior to mixing with the basal diet. The control diet, without feeding stimulants, was prepared using the same procedure as the flavoured diet.

\section{Procedure of Experiment}

The feeding regime was conducted as follows: fish were fed the diets ad libitum for 30 min every morning (at 9:00 A.M.) for 25 days. The feed intake was measured as dry weight basis. Initially, at 13 days, and at the end of the experiment, four fish were removed from each group at 3 and $6 \mathrm{~h}$ after feeding. The activities of digestive enzymes in the gastrointestinal tissue and digesta were assayed. The apparent digestibilities of dietary protein and carbohydrate were measured using the intestinal digesta at $6 \mathrm{~h}$ after feeding on the final feeding day of the experiment. The pancreas was included in the intestinal tissue.

\section{Enzyme Assay}

Pepsin-like activity (EC 3.4.4.1) in gastric tissue

* Laboratory of Fish Nutrition, Faculty of Agriculture, Kochi University, Nankoku, Kochi 783, Japan (潼

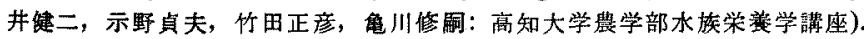


Table 1. Compositions of basal diet and flavour mixture

\begin{tabular}{lr}
\hline Ingredients & $\%$ \\
\hline Basal diet & 40 \\
White fish meal & 30 \\
Casein (vitamin free) & 5 \\
Pollack liver oil (powder) & 21 \\
$\alpha$-Potato starch & 2 \\
Vitamin mixture*1 & 2 \\
Mineral mixture*1 & \\
Proximate composition (on dry basis) & 55.3 \\
Crude protein & 5.5 \\
Crude fat & 22.9 \\
Digestible carbohydrate & 8.3 \\
Ash & $\mathrm{mg}$ \\
Flavour mixture*2 & 285 \\
L-Alanine & 508 \\
Glycine & 39 \\
L-Histidine & 217 \\
L-Proline & 63 \\
Uridine-5'-monophosphate $\cdot 2 \mathrm{Na}$ & \\
\hline *1 Halver's mixture.20) & \\
*2 Takeda et al.21) &
\end{tabular}

and its digesta and trypsin-like (EC 3.4.4.4) and amylase (EC 3.2.1.1) activities in intestinal tissue and its digesta were measured using the same methods as reported previously." Enzyme activities were expressed as $\mu$ mol tyrosine or glucose liberated per one min per $g$ of tissue or digesta, or per $100 \mathrm{~g}$ body weight as total activity.

\section{Assay for Digestibility and TCA-Soluble Nitrogen}

Apparent digestibilities of dietary protein and carbohydrate were determined by the indirect method of Furukawa and Tsukahara ${ }^{87}$ using $\mathrm{Cr}_{2} \mathrm{O}_{8}$ as indicator. Trichloroacetic acid (TCA) soluble nitrogen was measured in the supernatant fluid after centrifuging the homogenate of gastric digesta and $10 \%$ TCA solution using the Kjeldahl method.

\section{Results}

\section{Performance and Chemical Composition of Eel}

Performance of eel fed the flavoured and unflavoured (control) diets for 25 days is shown in Table 2. The total feed intake increased by $12.6 \%$ in the flavoured group as compared with the control group. The total body weight gain and feed efficiency in the flavoured group were twofold higher than those in the control group. The protein efficiency ratio, protein, fat and energy retained in the flavoured group were also remarkably higher than the control group. These results
Table 2. Performance of eel fed flavoured and control diet for 25 days

\begin{tabular}{lcc}
\hline Diet group: & Flavoured & Control \\
\hline No. of fish & 30 & 30 \\
Av. body wt (g) & & \\
$\quad$ initial & 77.6 & 77.7 \\
$\quad$ final & 93.3 & 80.6 \\
Total wt gain (g) & 489.0 & 201.2 \\
Feed intake $(\mathrm{g})$ & 451.8 & 401.1 \\
Daily feeding rate $(\%)$ & 0.70 & 0.66 \\
Survival rate $(\%)$ & 100 & 93.3 \\
Feed efficiency $(\%)$ & 108.2 & 50.2 \\
Protein efficiency ratio & 1.96 & 0.91 \\
Protein retained $(\%)$ & 34.4 & 16.0 \\
Fat retained $(\%)$ & 334.5 & 148.4 \\
Energy retained $(\%)$ & 78.6 & 35.9 \\
\hline
\end{tabular}

Table 3. Proximate composition (\%) of eel fed flavoured and control diet

\begin{tabular}{lcccc}
\hline Diet group & $\begin{array}{c}\text { Mois- } \\
\text { ture }\end{array}$ & $\begin{array}{c}\text { Crude } \\
\text { protein }\end{array}$ & $\begin{array}{c}\text { Crude } \\
\text { fat }\end{array}$ & Ash \\
\hline Initial & 65.6 & 16.3 & 15.9 & 1.8 \\
Final & & & & \\
$\quad$ Flavoured & 65.0 & 17.6 & 17.0 & 2.2 \\
$\quad$ Control & 65.0 & 17.6 & 16.3 & 1.8 \\
\hline
\end{tabular}

confirmed the previous observations on the effects of feeding stimulants on eel growth. ${ }^{2)}$

As is evident from the proximate composition of the whole body (Table 3), there were no marked differences and changes between the groups during the feeding period. This indicates feeding stimulants did not have any adverse effects on the body composition.

Weight of Each Organ and Gastrointestinal Digesta The weight of gastric and intestinal organ and their digesta were measured at 3 and $6 \mathrm{~h}$ after feeding, and their calculated relative values to body weight are shown in Table 4. In comparison of the relative intestinal digesta weight in the control group with that in the flavoured group, the large values were observed throughout the experimental period, and there were significant differences $(p<0.05)$ between the groups on the final feeding day. The relative intestinal organ weights were also remarkably higher in the control group on day 13 and final feeding day with a significant difference between the groups at $6 \mathrm{~h}$ after feeding on the final day of the experimental period. The relative liver weights in the flavoured group were lower than those in the control group. 
Table 4. Relative weights of liver, gastrointestinal organ and its digesta to body weight (\%)

\begin{tabular}{|c|c|c|c|c|}
\hline \multirow{3}{*}{$\begin{array}{l}\text { Hour after feeding: } \\
\text { Diet group: }\end{array}$} & \multicolumn{2}{|c|}{ Initial } & \multicolumn{2}{|c|}{13 days } \\
\hline & 3 & 6 & \multicolumn{2}{|c|}{6} \\
\hline & Commercial & Commercial & Control & Flavoured \\
\hline Body wt (g) & $99.1 \pm 9.3$ & $73.5 \pm 5.9$ & $100.5 \pm 16.9$ & $92.4 \pm 14.5$ \\
\hline Liver $(\%)$ & $1.94 \pm 0.36$ & $1.75 \pm 0.20$ & $1.94 \pm 0.17$ & $1.36 \pm 0.18$ \\
\hline Gastric organ $(\%)$ & $0.51 \pm 0.06$ & $0.74 \pm 0.10$ & $0.71 \pm 0.07$ & $0.65 \pm 0.26$ \\
\hline Gastric digesta $(\%)$ & $3.84 \pm 0.71$ & $3.10 \pm 1.69$ & $2.14 \pm 1.27$ & $1.55 \pm 1.03$ \\
\hline Intestinal organ $(\%)$ & $1.69 \pm 0.22$ & $1.72 \pm 0.10$ & $1.73 \pm 0.30$ & $1.42 \pm 0.22$ \\
\hline \multirow[t]{2}{*}{ Intestinal digesta $(\%)$} & $0.51 \pm 0.28$ & $0.64 \pm 0.26$ & $1.32 \pm 0.86$ & $0.51 \pm 0.34$ \\
\hline & \multicolumn{4}{|c|}{ Final } \\
\hline Hour after feeding: & \multicolumn{2}{|c|}{3} & \multicolumn{2}{|c|}{6} \\
\hline Diet group: & Control & Flavoured & Control & Flavoured \\
\hline Body wt (g) & $90.2 \pm 15.2$ & $99.5 \pm 19.9$ & $91.4 \pm 18.5$ & $117.1 \pm 15.8$ \\
\hline Liver $(\%)$ & $1.74 \pm 0.21$ & $1.63 \pm 0.31$ & $1.70 \pm 0.16$ & $1.42 \pm 0.21$ \\
\hline Gastric organ $(\%)$ & $0.67 \pm 0.24$ & $0.74 \pm 0.19$ & $0.55 \pm 0.12$ & $0.51 \pm 0.13$ \\
\hline Gastric digesta $(\%)$ & $1.76 \pm 0.32$ & $1.40 \pm 0.44$ & $0.71 \pm 0.42$ & $0.83 \pm 0.79$ \\
\hline Intestinal organ $(\%)$ & $1.66 \pm 0.04$ & $1.47 \pm 0.19$ & $1.52 \pm 0.12$ & $1.22 \pm 0.08$ \\
\hline Intestinal digesta $(\%)$ & $0.69 \pm 0.08$ & $0.35 \pm 0.16$ & $0.80 \pm 0.22$ & $0.21 \pm 0.03$ \\
\hline
\end{tabular}

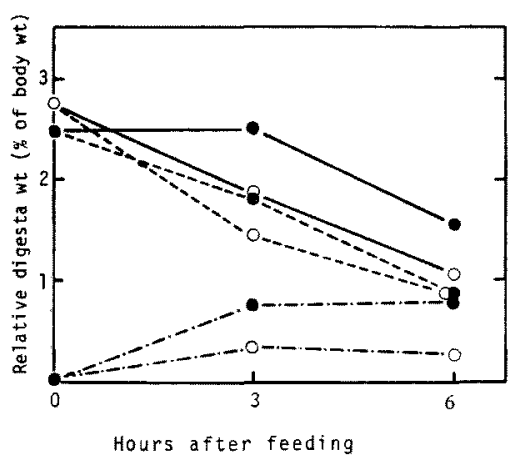

Fig. 1. Changes in gastrointestinal digesta after feeding. $\bigcirc$ Flavoured group, Control group -..- gastric digesta,

- - intestinal digesta,

_- gastrointestinal digesta.

Whereas, the relative gastric organ weights were similar in both groups, there were no appreciable differences in the relative gastric digesta weight between the groups.

Fig. 1 shows the changes in weight of gastrointestinal digesta of both groups at various times on the final feeding day. The values are expressed as relative weights of digesta to body weight. The relative weight of gastric digesta in both groups decreased linearly without a remarkable difference. However, the relative weight of intestinal digesta in the flavoured group was remarkably lower than that in the control group at 3 and
Table 5. Apparent digestibilities of diets

\begin{tabular}{|c|c|c|c|}
\hline \multirow{2}{*}{$\begin{array}{l}\text { Diet } \\
\text { group }\end{array}$} & \multicolumn{2}{|c|}{$\begin{array}{c}\text { Apparent digestibility } \\
(\%)\end{array}$} & \multirow{2}{*}{$\begin{array}{c}\text { Nitrogen* } \\
\text { in } \\
\text { TCA-soluble } \\
\text { fraction }\end{array}$} \\
\hline & protein & carbohydrate & \\
\hline Flavoured & 88.4 & 87.8 & 3.80 \\
\hline Control & 85.3 & 77.1 & 3.39 \\
\hline
\end{tabular}

* Nitrogen $\mathrm{mg} / \mathrm{g}$ wet gastric digesta.

$6 \mathrm{~h}$ after feeding. Therefore, the relative weight of the total gastrointestinal digesta in the flavoured group decreased immediately after feeding, whereas that in the control group decreased after $3 \mathrm{~h}$.

\section{Apparent Digestibilities of Dietary Protein and Carbohydrate}

Apparent digestibilities of dietary protein and carbohydrate were assayed in intestinal digesta at $6 \mathrm{~h}$ after feeding on the final experimental day. Although digestibilities were generally high in both groups, the flavoured group were 3.1 and $10.7 \%$ higher in the digestibilities of dietary protein and carbohydrate respectively, than the control group (Table 5). TCA-soluble nitrogen in gastric digesta at $6 \mathrm{~h}$ after feeding on the final feeding day was also about $10 \%$ higher in the flavoured group.

\section{Digestive Enzyme Activities in Gastrointestinal Tissue and Digesta}

The protease and amylase activities in the gastrointestinal tissue and their digesta in the flavoured 
Table 6. Protease and amylase activities in gastrointestinal tissue and its digesta

\begin{tabular}{|c|c|c|c|c|}
\hline \multirow{3}{*}{$\begin{array}{l}\text { Hour after feeding: } \\
\text { Diet group: }\end{array}$} & \multicolumn{2}{|c|}{ Initial } & \multicolumn{2}{|c|}{13 days } \\
\hline & \multirow{2}{*}{$\frac{3}{\text { Commercial }}$} & \multirow{2}{*}{$\frac{6}{\text { Commercial }}$} & \multicolumn{2}{|c|}{6} \\
\hline & & & Control & Flavoured \\
\hline \multicolumn{5}{|c|}{ Proteolytic enzyme activity* } \\
\hline \multicolumn{5}{|c|}{ Gastric tissue } \\
\hline per $\mathbf{g}$ tissue & $47.7 \pm 13.2$ & $34.9 \pm 1.82$ & $6.62 \pm 2.26$ & $4.42 \pm 2.53$ \\
\hline per $100 \mathrm{~g} \mathrm{~B} . \mathrm{wt}$ & $32.1 \pm 13.4$ & $25.9 \pm 3.09$ & $4.58 \pm 1.21$ & $2.65 \pm 1.32$ \\
\hline \multicolumn{5}{|l|}{ Gastric digesta } \\
\hline per $\mathbf{g}$ digesta & $0.05 \pm 0.04$ & $0.05 \pm 0.02$ & $0.25 \pm 0.31$ & $0.28 \pm 0.05$ \\
\hline per $100 \mathrm{~g} \mathrm{~B}$. wt & $0.15 \pm 0.05$ & $0.13 \pm 0.07$ & $0.29 \pm 0.29$ & $0.25 \pm 0.12$ \\
\hline \multicolumn{5}{|l|}{ Intestinal tissue } \\
\hline per $\mathrm{g}$ tissue & $15.6 \pm 10.1$ & $7.78 \pm 5.52$ & $14.7 \pm 4.58$ & $15.7 \pm 5.41$ \\
\hline per $100 \mathrm{~g} \mathrm{~B}$. wt & $26.7 \pm 19.0$ & $13.9 \pm 10.1$ & $25.7 \pm 9.27$ & $21.9 \pm 7.29$ \\
\hline \multicolumn{5}{|l|}{ Intestinal digesta } \\
\hline per $\mathrm{g}$ digesta & $28.2 \pm 8.83$ & $18.4 \pm 3.16$ & $31.0 \pm 10.8$ & $31.5 \pm 14.3$ \\
\hline per $100 \mathrm{~g} \mathrm{~B}$. wt & $16.0 \pm 10.1$ & $13.8 \pm 2.27$ & $45.3 \pm 43.2$ & $14.5 \pm 6.18$ \\
\hline \multicolumn{5}{|c|}{ Amylolytic enzyme activity* } \\
\hline \multicolumn{5}{|c|}{ Intestinal tissue } \\
\hline per $\mathbf{g}$ tissue & $3.10 \pm 2.16$ & $2.21 \pm 1.46$ & $2.44 \pm 0.30$ & $1.91 \pm 0.94$ \\
\hline \multirow[t]{2}{*}{ per $100 \mathrm{~g} \mathrm{~B}$. wt } & $1.59 \pm 1.82$ & $1.43 \pm 1.38$ & $4.14 \pm 0.34$ & $2.55 \pm 0.93$ \\
\hline & \multicolumn{4}{|c|}{ Final } \\
\hline \multirow{2}{*}{$\begin{array}{l}\text { Hour after feeding: } \\
\text { Diet group: }\end{array}$} & \multicolumn{2}{|c|}{3} & \multicolumn{2}{|c|}{6} \\
\hline & Control & Flavoured & Control & Flavoured \\
\hline \multicolumn{5}{|c|}{$\begin{array}{l}\text { Proteolytic enzyme activity* } \\
\text { Gastric tissue }\end{array}$} \\
\hline per $\mathrm{g}$ tissue & $48.4 \pm 10.1$ & $58.8 \pm 6.79$ & $44.9 \pm 13.0$ & $54.3 \pm 12.2$ \\
\hline per $100 \mathrm{~g} \mathrm{~B}$. wt & $32.3 \pm 13.1$ & $44.0 \pm 13.2$ & $25.9 \pm 12.3$ & $28.8 \pm 13.6$ \\
\hline \multicolumn{5}{|l|}{ Gastric digesta } \\
\hline per $\mathbf{g}$ digesta & $0.10 \pm 0.07$ & $0.20 \pm 0.09$ & $0.26 \pm 0.06$ & $0.24 \pm 0.12$ \\
\hline per $100 \mathrm{~g} \mathrm{~B}$. wt & $0.19 \pm 0.17$ & $0.30 \pm 0.20$ & $0.17 \pm 0.08$ & $0.17 \pm 0.18$ \\
\hline \multicolumn{5}{|l|}{ Intestinal tissue } \\
\hline per $\mathbf{g}$ tissue & $21.9 \pm 1.93$ & $24.4 \pm 8.11$ & $17.5 \pm 5.24$ & $21.5 \pm 7.34$ \\
\hline per $100 \mathrm{~g} \mathrm{~B}$. wt & $30.9 \pm 9.49$ & $36.1 \pm 13.0$ & $24.2 \pm 11.6$ & $25.9 \pm 8.11$ \\
\hline \multicolumn{5}{|l|}{ Intestinal digesta } \\
\hline per $\mathrm{g}$ digesta & $64.6 \pm 14.0$ & $49.5 \pm 14.7$ & $40.5 \pm 2.76$ & $36.7 \pm 17.8$ \\
\hline per $100 \mathrm{~g} \mathrm{~B}$. wt & $44.6 \pm 12.7$ & $17.5 \pm 8.33$ & $32.9 \pm 10.7$ & $7.51 \pm 3.53$ \\
\hline \multicolumn{5}{|c|}{$\begin{array}{l}\text { Amylolytic enzyme activity* } \\
\text { Intestinal tissue }\end{array}$} \\
\hline per $g$ tissue & $1.12 \pm 0.69$ & $1.61 \pm 0.58$ & $2.24 \pm 1.01$ & $0.93 \pm 0.73$ \\
\hline per $100 \mathrm{~g} \mathrm{~B}$. wt & $2.01 \pm 1.31$ & $2.53 \pm 1.29$ & $3.67 \pm 1.37$ & $0.94 \pm 0.73$ \\
\hline
\end{tabular}

and control groups are shown in Table 6. There were no significant differences in the pepsin- and trypsin-like activities per $\mathrm{g}$ of gastrointestinal tissue between the groups, though both enzyme activities considerably changed with time after feeding as shown in the previous paper. ${ }^{5}$ However, the pepsin-like activity in gastric digesta of the flavoured group was twofold higher than the control group at $3 \mathrm{~h}$ after feeding on the final experimental day and was equivalent to that at $6 \mathrm{~h}$. Whereas, the intestinal digesta of the flavoured group had significantly lower trypsinlike activities per $100 \mathrm{~g}$ of body weight than those of the control group, this difference was obscure in terms of the activity per $g$ of digesta. This is attributed to the higher level of relative intestinal digesta weight to body weight in the control group. 


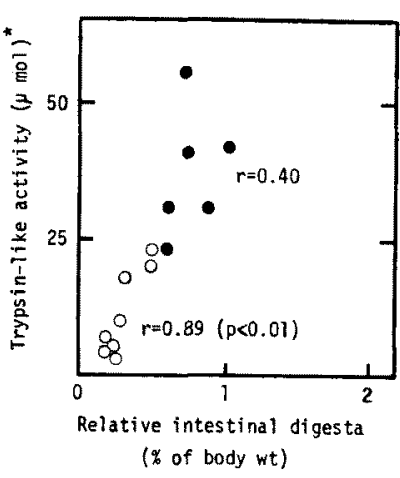

Fig. 2. Relationship between relative intestinal digesta wt and trypsin-like activity.

* Total activity.

Flavoured group, Control group.

The intestinal tissue of the flavoured group had lower amylase activities than those of the control group at $6 \mathrm{~h}$ after feeding on day 13 and the final day. However, a reverse relationship was detected at $3 \mathrm{~h}$ on the final feeding day.

\section{Discussion}

In mammals, the gastric juice is secreted from their chief cells controlled by cephalic, gastric and intestinal phases. The cephalic phase including anticipation of eating is the most potent, and accounts for more than one third of the total gastric secretion in dogs. ${ }^{7)}$ In the previous paper, ${ }^{5)}$ we suggested protein digestion in the gastric tract as considerably weak compared to the intestinal tract based on the level of protease activity in their digesta. In the present experiment, the pepsin-like activity in the gastric digesta was maintained at lower level than the trypsinlike activity in intestinal digesta as reported previously. Whereas, higher pepsin-like activity was recognized in the flavoured group at $3 \mathrm{~h}$ after feeding on the final feeding day and was equivalent to that at $6 \mathrm{~h}$. Also, higher TCA-soluble nitrogen amount in gastric digesta was determined in the flavoured group, compared with those of the control group. It is suggested from these results that gastric protease in the flavoured group was secreted promptly and immediately after feeding, thus gastric digestion was promoted. This is the first observation on gastric secretion in fish promoted by feeding stimulants in diet, and this might be related to the stimulation via cephalic phase as reported for mammals. ${ }^{1}$

There are many reports concerning the intestinal digestion in rats. ${ }^{8-14}$ ) Naim et al. ${ }^{15)}$ suggested rat fed on saccharin supplemented aversive diet resulted in higher protease activity in both pancreas and intestine and greater intestinal digesta. Percival and Schneeman $^{11)}$ reported rats fed a heat-damaged casein diet increased the protease activity in pancreas and intestinal digesta. The present results showed the trypsin-like activity in intestinal digesta was considerably low in the flavoured group as compared to the control group. Therefore, the lower protease activity in the intestinal digesta in the flavoured group suggested a more efficient digestion and absorption than the control group showing the comparatively higher activity. The rapid decreasing of relative gastric digesta weight and significantly low level of relative intestinal digesta after feeding were observed in the flavoured group on the final feeding day (Fig. 1). These coincided with the result of apparent digestibilities. Therefore, digestion and absorption in eel intestine fed the flavoured diet may be partially due to the potent gastric digestion as described previously in this report.

In rats, the secretion of pancreatic protease was related to the amounts of digesta and peptides being introduced into the intestinal tract. ${ }^{8}$. The negative feedback regulation between the secretion of pancreatic protease and the protease level in intestinal digesta in rat was reported by Schneeman and Lyman. ${ }^{18)}$ The relationship between the relative intestinal digesta weight and total protease activity are shown in Fig. 2. The correlations coefficient in the flavoured group was $r=0.89$ indicating a significant relationship in contrast to the control group where $r=0.45$ indicating insignificant relationship. The same result has been obtained in the previous experiment using eel fed a flavoured diet.5) This result indicates that the secretion of protease into the intestinal tract may be regulated depending upon the amounts of intestinal digesta introduced from the gastric tract which was more regulated effectively in the flavoured group than in the unflavoured group. Barrington and Dockrey ${ }^{18)}$ suggested the existence of cholecystokinine-like substance in eel intestinal homogenate. Therefore, the secretion of intestinal protease in the flavoured group might be regulated by this gastrointestinal hormone as documented in higher vertebrates. ${ }^{19)}$

It is reconfirmed from these results that the feed intake, weight gain, feed efficiency and nutrient retentions in eel fed the flavoured diet were higher than those of eel fed the unflavoured diet. The reasons for this good performance in the 
flavoured group were partially explained by their high digestibilities in response to the effective secretion of digestive protease in gastrointestinal tract. Moreover, this might partially be attributed to the stimulating hepatic enzyme activities relating to amino acid and carbohydrate metabolism. This aspect of hepatic enzyme activity is presently being investigated in our laboratory.

\section{Acknowledgements}

We are indebted to Mr. T. Imaue in Kochi-ken Shiryou Chikusan Co., Ltd. for his advices and to Mr. H. Hosokawa and Miss. D. V. Baxa in Kochi University for their helpful guidance and reading the paper.

\section{References}

1) K. Yumikari and K. Torii: in "Mikaku no Kagaku" (ed. by M. Satou), Asakura shoten, Tokyo, 1981, pp. 244-266.

2) K. Takii, M. Takeda, and Y. Nakao: Bull. Japan. Soc. Sci. Fish., 50, 1039-1043 (1984).

3) K. Ina: Bull. Japan. Soc. Sci. Fish., 47, 627630 (1981).

4) K. Ina: Bull. Japan. Soc. Sci. Fish., 47, 13511354 (1981).

5) K. Takii, S. Shimeno, and M. Takeda: Bull. Japan. Soc. Sci. Fish., 51, 2027-2032 (1985).

6) A. Furukawa and H. Tsukahara: Bull. Japan.
Soc. Sci. Fish., 32, 502-506 (1966).

7) L. Olbe: Gastrointerology, 44, 463-468 (1963).

8) G. M. Green, B. A. Olds, G. Mattews, and R. L. Lyman: Proc. Soc. Exp. Biol. Med., 142, $1162-$ 1167 (1973).

9) M. Lavau, R. Bazin, and J. Herzog: J. Nutr., 104, 1432-1437 (1974).

10) B. O. Schneeman, I. Chang, L. B. Smith, and R. L. Lyman: J. Nutr., 107, 281-288 (1977).

11) S. S. Percival and B. O. Schneeman: J. Nutr, 109, 1609-1614 (1979).

12) S. G. Kirschenmann and B. O. Schneeman: $J$. Food Sci., 47, 714-719 (1982).

13) B. O. Schneeman and D. Gallaher: J. Nutr, 110, 584-590 (1980).

14) G. M. Green and E. S. Nasset: J. Nutr., 113, 2245-2252 (1983).

15) M. Naim, J.G. Brand, and M.R. Kare: J. Nutr., 112, 2104-2115 (1982).

16) B. O. Schneeman and R. L. Lyman: Proc. Soc. Exp. Biol. Med., 148, 897-903 (1975).

17) M. Naim, J. G. Brand, M. R. Kare, N. A. Kaufmann, and C. M. Kratz: Physiol. Behav., 25, 609-614 (1980).

18) E. J. W. Barrington and G. J. Dockray: Gen. Comp. Endocrinol., 19, 80-87 (1972).

19) L. O. Uttenthal: Proc. Nutr. Soc., 44, 53-61 (1985).

20) J. E. Halver: J. Nutr., 62, 225-243 (1957).

21) M. Takeda, K. Takii, and K. Matsui: Bull. Japan. Soc. Sci. Fish, , 50, 645-651 (1984). 